Aging Nationally in Contemporary Poland 


\title{
Global Perspectives on Aging
}

\author{
Series editor, Sarah Lamb
}

This series publishes books that will deepen and expand our understanding of age, aging, ageism, and late life in the United States and beyond. The series focuses on anthropology while being open to ethnographically vivid and theoretically rich scholarship in related fields, including sociology, religion, cultural studies, social medicine, medical humanities, gender and sexuality studies, human development, critical and cultural gerontology, and age studies. Books will be aimed at students, scholars, and occasionally the general public.

Jason Danely, Aging and Loss: Mourning and Maturity in Contemporary Japan

Parin Dossa and Cati Coe, eds., Transnational Aging and Reconfigurations of Kin Work

Sarah Lamb, ed., Successful Aging as a Contemporary Obsession: Global Perspectives Margaret Morganroth Gullette, Ending Ageism, or How Not to Shoot Old People Ellyn Lem, Gray Matters: Finding Meaning in the Stories of Later Life

Michele Ruth Gamburd, Linked Lives: Elder Care, Migration, and Kinship in Sri Lanka

Yohko Tsuji, Through Japanese Eyes: Thirty Years of Studying Aging in America Jessica C. Robbins, Aging Nationally in Contemporary Poland: Memory, Kinship, and Personhood 


\section{Aging Nationally in Contemporary Poland}

\section{Memory, Kinship, and Personhood}

JESSICA C. ROBBINS

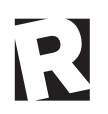

Rutgers University Press

New Brunswick, Camden, and Newark, New Jersey, and London 
Library of Congress Cataloging-in-Publication Data

Names: Robbins, Jessica C., author.

Title: Aging nationally in contemporary Poland: memory, kinship, and personhood / Jessica C. Robbins.

Description: New Brunswick: Rutgers University Press, [2020] | Series: Global perspectives on aging | Includes bibliographical references and index.

Identifiers: LCCN 2020010824 | ISBN 9781978813960 (paperback) | ISBN 9781978813977 (cloth) |

ISBN 9781978813984 (epub) | ISBN 978197881399I (mobi) | ISBN 9781978814004 (pdf)

Subjects: LCSH: Aging-Social aspects_Poland. | Older people-Poland-Social conditions. | Health promotion-Poland.

Classification: LCC HQ1064.P6 R63 2020| DDC 305.2609438-dc23

LC record available at https://lccn.loc.gov/2020010824

A British Cataloging-in-Publication record for this book is available from the British Library.

All photos by the author

Copyright (C) 2021 by Jessica C. Robbins

All rights reserved

No part of this book may be reproduced or utilized in any form or by any means, electronic or mechanical, or by any information storage and retrieval system, without written permission from the publisher. Please contact Rutgers University Press, I06 Somerset Street, New Brunswick, NJ $\circ 890$ I. The only exception to this prohibition is "fair use" as defined by U.S. copyright law.

$\otimes$ The paper used in this publication meets the requirements of the American National Standard for Information Sciences-Permanence of Paper for Printed Library Materials, ANSI Z39.48-I992.

www.rutgersuniversitypress.org

Manufactured in the United States of America 
In memory of my grandparents, Rovelle Coffman Choate, Pauline Davis Choate, Alvin Dolliver Robbins, and Jean West Robbins 
